\title{
Local Government's Economic Response to COVID-19: The Case of eThekwini City Council in Durban, South Africa
}

\author{
Ajiv Maharaj \\ ORCiD iD: https://orcid.org/0000-0001-6798-057

\section{Purshottama Reddy \\ ORCiD iD: $\underline{\text { https://orcid.org/0000-0001-9237-6272 }}$}

\section{Abstract}

COVID-19 is an unprecedented influenza type infection that is caused by the corona virus. The disastrous consequence of the infection is that it can be transmitted very rapidly resulting in a major global pandemic. In the absence of a vaccine to prevent and consequently treat COVID-19, national governments, the World Health Organisation (WHO) and relevant global development partners are working feverishly to develop counter actions to respond to the crisis. National and subnational governments are at different stages of the outbreaks, responding accordingly relative to their resources and capacity. Local governments globally have a critical role to play in responding to the crisis as they are at the coalface dealing with local communities. This article reviewed the role of local governments in responding to the pandemic, using the eThekwini City Council as a case study. eThekwini City Council is located in the Province of Kwazulu-Natal with a budget in excess of over R 50 billion rand, a staff complement of over 24000 employees and a population that exceeds 3.7 million people is one of eight metropolitan municipalities in South Africa. The research methodology adopted for the article included: (1) the findings of an online business survey conducted by eThekwini Municipality and the municipal response in developing an economic recovery plan, based on the findings from the survey; and (2) a documentary analysis of publications of the South African Government; World Bank and international development organisations; WHO and eThekwini Municipality Council. 
Within this context, the critical role of local government in economic support and recovery from the economic crisis brought about by this virus was examined. According to studies reviewed, COVID-19 was largely concentrated in cities, and hence the role of municipal actors in managing the health and economic impacts of the virus, are important and relevant to the current context. The research examined the role of city governments in supporting businesses and facilitating economic recovery in the broader context of the COVID-19 pandemic. The research demonstrated that most interventions related to COVID-19 have been driven primarily from National Governments, focusing on first, an extra-ordinary health response and secondly, a financial stimulus to facilitate economic recovery. The eThekwini Plan with an 18-month timeframe, complements and supports the measures introduced by National Government for facilitating economic recovery and relief provision. The eThekwini City Council case study is hence worth noting and adds to this rapidly developing field and knowledge base on local economic development during the COVID-19 calamity.

Keywords: COVID-19; case - study; economic response; eThekwini City Council and local government.

\section{Introduction}

The world is faced with an unprecedented challenge in the form of the COVID19 pandemic. Since its first discovery in China in December 2019 the virus has spread, to almost every country. During this time, it has infected at least 30 million people killing 950000 (as at 18 September 2020). South Africa has not been spared with its first case reported on 05 March 2020 which rapidly rose to 655572 cases and 15772 deaths as of 18 September 2020 (www.Worldometers.info/coronavirus/; accessed on 18 September 2020). The President declared a National State of Disaster on 15 March 2020 and prohibited gatherings of more than 100 persons. A 21-day lockdown was introduced by the government on 27 March which was later extended for an additional 2 weeks to 30 April 2020. However, from 01 May 2020 the country moved to level 4 of the lockdown which allowed some activities to resume while still restricting travel and non-essential activities. On 01 June 2020 the country moved to level 3 of the lockdown which allowed greater movement and opening up of the economy (Republic of South Africa 2020a Government 
Gazette No. 43096 of 15 March 2020; Republic of South Africa 2020d Government Gazette No. 43258 of 29 April 2020; Republic of South Africa 2020e Government Gazette No. 43291 of 07 May 2020 and Republic of South Africa 2020b Department of Co-operative Governance, Government Notice 318 of 18 March 2020)

The Risk Adjusted Strategy adopted by the South African Government proposed a phased lockdown and re-opening of the economy to limit the spread of COVID-19 and 'flatten the curve'. The swift action of government in locking down the economy and banning travel has no doubt played a major role in decelerating the spread of the virus and bought the country some time to prepare a large-scale health response (Science Magazine 2020).

The eThekwini Municipal area is centred on the City of Durban located on the eastern seaboard of the country with a population of 3.7 million people (Stats SA 2016). eThekwini's economy has not been spared the wrath of COVID-19 with an estimated 327000 jobs being lost, a sharp contraction in Gross Domestic Product (GDP) and widespread strife (The Durban EDGE 2020a). The National Government has announced two, of a total of three phases of socio-economic support measures to fight the virus, care for the afflicted and support for an ailing economy. The second phase announced on $21^{\text {st }}$ April 2020 totals R500 billion or 10\% of GDP (National Treasury 2020a).

\section{Literature Review}

\subsection{Overview}

Baldwin and Weder di Munro (2020) accurately summarises the global situation relative to the COVID-19 pandemic:

The COVID-19 crisis has become more predictable in a sense. What was widely viewed as a 'Chinese problem', and then an 'Italian problem' has become an 'everybody problem'. With few exceptions, governments initially downplayed the disease until sustained community transmission takes hold. Then they imposed severe social distancing policies, work and school closures and the like. This inevitably leads to almost immediate economic hardship, which then leads governments to propose increasingly bold anti-recession measures. This was the pattern in Europe and looks set to be the pattern in the US and many other nations. All this is due to the highly 
contagious nature of the virus, and the inexorable implications of its explosive spread during the 'acceleration phase' of the epidemic (2020: 1).

Their advice for policy makers is to 'act fast and do whatever it takes' (Baldwin \& Weder di Munro 2020: 14) to compress the slump, while avoiding damage viewed as long term to global economies. They note that this advice is premised on the assumption that the medical reality is fleeting, and is likely to gradually disappear as a vaccine is developed and treatments which are curative. Hence, they point out that the pandemic will end. However, the damage economically could be obstinate and in the absence of measures which are preventative, jobs may disappear after the recession, and a large number of businesses might end up bankrupt, and the balance sheets both of financial institutions and government could be severely impacted on. They argue that a possible solution is to decrease the build-up of 'economic scar tissue' by controlling the amount of preventable corporate and private bankruptcies, and to ensure that the populace have adequate funds to continue spending even if they are not employed. Odendahl and Springford (2020) map out the two economic stages of the Coronavirus and the economic responses that are required from governments and the European Central Bank at each of these stages. They argue that policymakers are required to offset the tremendous costs of containing the virus, while putting in place fiscal measures to keep debt sustainable. They argue that while this is happening, governments should be planning to stimulate the economy to bring about a V-shaped economic recovery.

The Organisation for Economic Cooperation and Development (OECD 2020), notes that surveys conducted showed that the lockdowns have had a large impact on Small, Medium and Micro Enterprises (SMMEs) across the globe. However, they point out that SMMEs in Germany were relatively less impacted due to the local nature of their supply chains. The report notes that many SMMEs are concentrated in the tourism, travel, fashion, and food sectors, all of which have been acutely impacted by COVID-19. The article summarises the key impacts on SMMEs as being, supply side constraints due to the impact on labour and supply chain disruptions; a drastic fall in demand; financial markets losing confidence resulting in less lending, and SMMEs being less resilient due to lower cash reserves or investments. The study notes that actions undertaken by governments have ranged from fiscal measures by central banks; eliminating procurement and payment delays and forward- 
looking support to move businesses online. Financial measures have included temporary tax relief, temporary disaster relief loans; direct financial support through low interest or interest free loans (OECD 2020).

Baldwin and Weder di Munro (2020) group the policy responses into six thematic areas of policy response consisting of fiscal; monetary; financial regulation; social insurance; industry policies and trade policies. In all these areas, the role of local government is seen as supportive.

The economic impact of COVID-19 on municipalities and local governments is relatively less documented in terms of published articles and books. Hence, much of the literature that is drawn on for the purposes of this article is based on presentations, reports, and unpublished works of various organisations such as the World Bank. The World Bank has been proactive in setting up webinars under the Competitive Cities Programme to share experiences among city practitioners around the globe. In South Africa, the National Treasury through its City Support Programme has convened virtual forums to share experiences among the cities in the country while improving the levels of co-ordination and co-operation between national departments and cities.

Sivaev (2020), as part of the World Bank's Competitive Cities Programme (See World Bank 2015 for more detailed information), examines the economic responses in 37 cities around the world and shares some of the common themes emerging in terms of good practices:

- The effect is varied in different cities based on impact connectedness, density, and other factors.

- Cities are the worst affected with $95 \%$ of the world's coronavirus cases in municipal jurisdictions in approximately 1,500 cities in excess of 210 countries. He notes that density makes cities more susceptible though variation between cities of the same density which implies that city management can have a large impact.

- Local government in most countries play a critical role in sustaining services, and managing emergency response, while defining and enforcing containment measures.

- First sectors to experience economic shock are non-tradable services. Local governments play a critical role to support these businesses (largely made up of SMEs and informal firms), even by ensuring that national governments help reach them. 
- Because impact is so place specific, rebuilding will require place specific approaches, that city leaders should orchestrate.

Sivaev (2020) notes that emergency response of cities so far can be summarized into six areas, namely social distancing and confinement workplace practices and commuting patterns; communication awareness raising and digital tools; support to business and economic recovery; local service delivery, targeted measures for vulnerable groups. He further notes that cities are not equal in their response within and across countries. Their response is shaped by authority delegated to them, their organizational and fiscal capacity, and their size (Sivaev 2020). He points out that cities that built coalitions and had a good grasp of the local economy before the crisis, such as Durban, appeared to be better positioned to handle the economic crisis.

Gentilini, Almenfi and Orton (2020) highlight the importance and need for social protection measures and job responses at the local level while noting that a return to pre-pandemic approaches and methods of stimulating the economy are no longer appropriate. They note that not only did the pandemic cause economic activity to plummet, it also exposed the fault lines that the economy was built, resulting in critical shifts and collapse. A key lesson for eThekwini Municipality Council from this is that shared growth cannot be achieved by a business-as-usual approach and strategic shifts are necessary.

\subsection{Global Economic Context}

The International Monetary Fund (2020) has recently revised the global growth for 2020 to $-3 \%$ which is the lowest since the Great Depression. The health calamity has triggered off an economic-financial crisis, compounded by a climate crisis. The international markets lost about $\$ 8$ trillion (South Africa and Argentina performed the worst during March). The leading economies of China and the US has recorded reduced export earnings, industrial production, retail sales, fixed investment, and services. The lockdown and social distancing, which began to affect these economies first has led to a decline in global production and employment. Despite the introduction of large stimulus packages in the US and Europe, the world economy is looming towards a recession and if not curtailed within 2020, a depression. This scenario is being played out elsewhere as the virus spreads (Moneyweb 2020).

As of 18 September 2020, there is no vaccine for the virus and some 
survivors seem to have an acquired immunity. The overall strategy is to slow down the rate of the contagion to relieve the hospital system and reduce the death rate. The termination of economic activities in its scale and abruptness has only been seen previously during world wars. During the first six months of 2020, there was an international scramble for three resources - masks, ventilators, and sanitizers. The medical community has indicated that a vaccine may only be ready and distributed in early to mid-2021 (World Economic Forum 2020)

Initially the perception was that COVID-19 will disappear like the Severe Acute Respiratory Syndrome (SARS) and Middle Eastern Respiratory Syndrome (MERS) outbreaks. However, it did not, and the long-term impact has touched on all aspects of one's daily existence, and is likely to cause unprecedented socio-economic upheaval and has exacerbated the conditions for those already trapped in poverty, unemployment and inequality. Globally, this pandemic has highlighted the social inequalities and exposed the structural deficiencies in society. The lockdown has laid bare South Africa's stark historical inequalities. This virus is a raw reminder of inequality and how, when crisis strikes the poor, it does so with a different strain of severity (Engineering News 2020).

The Virus has also had a major impact on the global trade in goods and services which have plummeted in the first and second quarters of 2020 as recorded by the World Trade Organisation (WTO). The Goods Trade Barometer generates real-time data on the trail of international merchandise trade relative to recent developments. The reading in June 2020 captures the early stages of the COVID-19 epidemic and is the lowest score on record with no indication of the decline in trade as yet bottoming out. This figure is in line with the WTO's trade forecast communique on 8 April 2020, which pointed out that global merchandise trade could decrease between $13 \%$ and $32 \%$ in 2020 , depending on the pandemic lifespan and policy response effectiveness (World Trade Organisation 2020).

All the barometers' constituent indices are at present well below trend (79.7). The weakest of all was the automotive products index, due to falling motor vehicle manufacturing and sales in the leading economies. The severe reduction in the progressive export orders index (83.3) puts forward that weaknesses in trade will continue in the short term. Reduction in the container shipping (88.5) and air freight (88.0) indices point to poor demand for goods merchandised as well as supply-side limitations arising from attempts to 
overcome the COVID-19 pandemic. Signs of stability are only being demonstrated in the indices for agricultural raw materials (95.7) and electrical components (94.0), despite both remaining lower than the current trend. There has been a reduction in trade in 2019 prior to the pandemic, weighed down by ongoing tensions in trade and economic growth which is weakening. The trade statistics of WTO demonstrate that the bulk of global merchandise trade contracted by $0.1 \%$ in 2019 , signifying the first yearly decline since 2009 , through the international financial crunch (World Trade Organisation 2020).

\subsection{South African Economic Context}

The South African economy is characterised by a rapid growth in its national debt burden, due in part to the State-owned utility Eskom. Eskom's debt has rendered it unviable in its current form without government subsidies. Eskom's debt has not come as a result of adding generation capacity and the utility has repeatedly found itself unable to meet national demand for electricity. This has been largely responsible for the economic recession that the country found itself in at the end of 2019. The country was then faced with the reality that its huge debt burden has not translated into significant infrastructure gain nor resulted in economic growth. This led to the sovereign rating downgrade to sub-investment grade by Moody's (the last rating agency that still rated the country at investment grade). While the electricity constraints are significant and long-term in nature, government's legislative amendments which allow for municipalities to generate their own electricity, is a significant opportunity for eThekwini City Council (Moody's Investor Services 2020).

According to the National Treasury (2020b), COVID-19 brought an added challenge to an economy that was already struggling with recession and deep structural challenges. The National Treasury anticipates the economy to decline by between $6 \%$ and $7 \%$ for 2020 . The lockdown is anticipated to have decimated economic activity in quarter two of 2020 rendering GDP growth as an irrelevant statistic in that quarter. This will see tax collection plummeting in 2020 and national debt levels accelerating in the short-term. While these challenges have placed the country on a downward spiral, an opportunity exists to use this period of crisis to make structural changes in the economy that could rescue the country and return it to a growth path. However, this will not be an easy road and may well require more sacrifice than the country is willing to 
make. In the short term, it is anticipated that the economy will return to prelockdown levels of economic activity in 2022.

At a national government level, intense scenario planning has recorded the commercial impact of the different levels of lockdown, as well as the ensuing routes for the fiscal shortfall, for state borrowing and for a financial reaction. At this stage, the overwhelming scenario is for a profound depression in 2020, followed by an upturn in growth economically. The National Treasury is in conversation with multilateral structures and their stakeholders, both local and domestic economists, and the South African Reserve Bank to understand how the global economy will adjust. Domestic and global high-frequency data are also being monitored to get an understanding of the ongoing evolution of the economy during this global pandemic. Various relief packages have been introduced to assist businesses, communities, and individuals during this time (National Treasury 2020b).

National Treasury has also affirmed that the additional parts of the deal includes the drawing down of current surpluses such as the Unemployment Insurance Fund (UIF) or enhancing the conditional liability of government securities. A key risk that the economy and fiscus will face post the COVID19 crisis is whether economic growth over the long term returns to the averages of between $1 \%$ - $2 \%$ prior to the pandemic. Economic growth at a faster tempo is required to address the deep structural challenges of inequality, unemployment, and poverty.

A major economic support and social relief programme of R500 billion to alleviate the impacts of COVID-19 country - wide was pronounced by the President. This package constitutes a portion of the second level of South Africa's 3-phase fiscal response to ensure the stability of the economy, respond to the decline in demand/supply and safeguard jobs. The social relief and economic support package for the second phase will cater for an increased health budget to respond to the Coronavirus, the relief of hunger and social distress, support to companies and workers and the phased re-opening of the economy. The procuring of the $\mathrm{R} 500$ billion has required the reprioritization of approximately R130 billion in the existing budget, the balance will be borrowed from BRICS and the World Bank. The rest will be raised from local sources such as the Unemployment Insurance Fund and from global partners and international finance institutions. To date, the government has approached the World Bank, International Monetary Fund, BRICS, New Development Bank, and the African Development Bank (National Treasury 2020b) for funding. 
The National Economic Recovery Plan is the third phase to startup economic recovery in the country as it arises from the contagion. This will focus on; economic sectors, investment, employment, and infrastructure development; governance, state capacity and industrial development; social protection, community, and human development; international cooperation, trade and security and justice, crime prevention and security. Phase two of the economic relief package consisted of R500 billion support which includes the following:

- R20 billion to finance the COVID-19 health response, i.e., protective equipment for health workers, community screening, increased testing capacity, additional beds in field hospitals, ventilators, medicine, and staffing;

- R20 billion to municipalities for emergency water supply, increased sanitization of public transport/facilities and food/shelter for the homeless;

- R50 billion in social relief for vulnerable families, temporary sixmonth COVID-19 grant, and special COVID-19 social relief distress grant;

- R100 billion to protect/create jobs;

- R40 billion income support/payments for workers not receiving wages.

- R2 billion to assist small, medium and micro enterprises, spaza shop owners and other small businesses;

- R200 billion loan guarantee scheme in partnership with major banks, the National Treasury and the SA Reserve Bank to cover operational costs (salaries/rent/payment of suppliers) of companies; and

- Reserve Bank has unlocked approximately R80 billion in the real economy by reducing the repo rate by 200 basis points and embarking on supplementary measures to provide greater liquidity to the financial system.

There has been significant focus on the economic performance of the country as a whole which led to the creation of the generic economic relief measures outlined above. However, more detailed analysis of economic performance at the city or metro scale provides greater insight into the challenges being experienced at the local level. 


\subsection{Durban's Economic Performance}

With the overall 2019 economic growth for the city coming in at $-0.1 \%$ (Quantec 2020), Durban left 2019 in recession with the prospect of enhanced economic performance in 2020. The City performed worse than the other large metros of Johannesburg, Cape Town, Tshwane and Ekurhuleni due to the poor performance of key sectors such as tourism, logistics and manufacturing. The congestion at the Durban Port which was widely reported in the local media in quarter 3 and 4 of 2019 provided a prelude to the poor performance of the logistics sector.

According to Quantec (2020) Durban's economy has also performed poorly over the last 12 years with fewer people employed in the city at the end of 2019, than in 2008. While 1210764 were in employment at the end of 2019, it is estimated that this figure fell by 327000 in quarter two of 2020, resulting in Durban's largest job loss ever recorded. The number of people employed as a percentage of the total working age population having reached a peak of about $52 \%$ in 2008 before gradually declining to $45 \%$ at the end of 2019 . This means that more people are unemployed than employed. While the employment numbers will gradually improve as more of the economy is reopened, it is expected to take about 18 months before reaching pre-lockdown levels (Durban Edge 2020).

The pandemic reduced the transport of goods, especially in the ports which impacted negatively on both the manufacturing and services sectors (social distancing is impacting on three quarters of those in the services sector, except those deemed essential). This combined with a ratings downgrade has resulted in capital flight and sharp depreciation as investors pull moneys out of emerging markets. The travel and tourism industry are being severely impacted due to restrictions in travel, but also a reluctance to travel once the travel bans are lifted. The accommodation sector as well as restaurants and recreational services are among the worst affected industries. Estimating GDP during the lockdown is not considered a meaningful measure as $70-80 \%$ of the economy was in lockdown during levels 5 and 4 . Hence a model was developed by eThekwini Municipality's economic intelligence programme called the Durban Edge, to estimate how the local economy will return and re-open during the different levels of lockdown particularly from level 5 through to level 3 (Durban Edge 2020b).

During level 4 of the lockdown, it is estimated that the city was 
operating at $34,2 \%$ of its 2018 capacity. It is also estimated that $32,2 \%$ of businesses were operational, although with a reduced workforce, and/ or reduced working hours. This considers businesses working from home; global and national lags in economic activity due to economic downturn and restrictions such as limits on employee numbers, operational capacity, etc. The top four sectors of activity during this level of the lockdown were financial and business services (13\%), manufacturing $(8,4 \%)$, transport storage and communication. $(3,5 \%)$ and wholesale and retail trade $(3,1 \%)$. It is further estimated that at level 3 of the lockdown, the city's economy operates at $42,2 \%$ of its capacity. It is also estimated that $36,8 \%$ of businesses were operational, with a reduced workforce, and/ or reduced working hours. The top four sectors of activity at level 3 consist of financial and business services (12,5\%), manufacturing $(9 \%)$, retail/wholesale trade $(3,7 \%)$ communication and transport storage (3.4\%) (The Durban EDGE 2020b).

The Durban EDGE (2020b) forecast is based on a sample of 12400 businesses in Durban; the Department of Health's Schedule of Services (Republic of SA 2020b), a match of permitted services at each level (Levels 3 and 4) to businesses in the database to illustrate increase in businesses operating, a corresponding estimate of Gross Value Added (GVA) contribution for permitted services at each level. This framework was applied to the rates database to gain insight on the number and make up of rate paying businesses operating under each level, and their economic performance. The report indicates that there is limited underlying data to forecast economic performance due to the dynamic nature of the economy and real time and forecasted data is limited. The ABSA Purchasing Manager's Index data on new sales orders in April 2020 was also factored into the Durban EDGE model. There is further limited/fragmented data on the informal economy (including private households, e-mailing services and street traders). The report estimates the informal economy makes up $18 \%$ of local enterprises (The Durban EDGE 2020b).

According to eThekwini Municipality (2020a) the economic fallout of COVID-19 has plunged the collection rate of municipalities into a downward momentum that will take years to repair. eThekwini Municipality reported that its collection rate of revenue fell from 94\% in February 2020 to 56\% in April 2020, resulting in an under-collection of R1,5 billion and putting the Municipality under financial stress. The Municipality estimates that it will lose approximately R8 billion in revenue as a result of COVID-19 in 2020. The 
City's Economic Recovery Plan (eThekwini Municipality 2020b) asserts that while eThekwini moves to limit the financial fallout of the pandemic, it must simultaneously move rapidly to repair the economic damage, protect jobs and care for the vulnerable. In this regard, the City took the lead in the country by not only putting in place health and social interventions, but to set out a path to economic recovery. The City's own research indicates that it will take no less than 18 months to get back to pre-lockdown levels of economic activity. At the same time, the reality is that the pre-lockdown levels of economic activity were fundamentally flawed in that the city's economy was already in recession while levels of inequality were deeply embedded in the structure of the economy.

\section{Research Methodology}

This article presents the findings of an online business survey conducted by eThekwini Municipality as well as the municipal response in developing an economic recovery plan which is based on the findings from the survey.

In response to the effects of the national and city level COVID-19 lockdown and mitigation measures on Durban's economy, the Municipality conducted an online survey through its Economic Development Unit. The survey had two aims. Firstly, to understand the impact that the lockdown was having on businesses and secondly what measures the Municipality could put in place to assist in an economic recovery. The survey was hence a means to provide the Municipality with direct insight into the challenges that firms were having and information on job loss.

The survey was conducted with businesses to gauge the needs of a cross-section of the Durban business community as discussed in 4.1 below. The target population consisted of representatives of firms that were in an executive management position which enabled them to have oversight of all areas of the firm's operations. The survey was sent to this target group and was open for them to complete over a two-week period. The sampling and data cleaning process ensured that there was no more than a single questionnaire completed per company. The survey was open for responses from the $31 \mathrm{March}$ 2020 to the 14 April 2020 and was sent out via an email link to a database of about 3000 businesses, representing a cross-section of businesses in Durban. The survey garnered responses from 99 businesses representing 3.3\% of the total database. 


\subsection{Profile of Respondents}

Businesses were categorised in terms of size based on the number of people employed. Micro businesses employed less than 5 people; very small businesses employed 6 to 20 people; small businesses employed 21 to 50 people; medium sized businesses had 51 to 200 employees while large businesses employed more than 200 people. Most respondents were small and micro businesses, with 41 respondents being micro businesses, 34 very small businesses and 11 being small businesses. A further 7 respondents were large businesses while 6 respondents were medium sized businesses. A total of 88 respondents were formal businesses while 11 were informal businesses. Most respondents were from trade and professional business services, including clothing retailers, and events firms. Most large companies were manufacturers, estate agents and communications firms.

\section{Table 1: Number of Respondents by Industry Classification}

\begin{tabular}{|l|l|}
\hline Industry Classification & Number of Respondents \\
\hline Trade & 20 \\
\hline Professional services & 19 \\
\hline Manufacturing & 14 \\
\hline Community services & 12 \\
\hline Communications & 9 \\
\hline Real Estate & 6 \\
\hline Catering and accommodation & 5 \\
\hline Transport and storage & 5 \\
\hline Construction & 5 \\
\hline Tourism services & 2 \\
\hline Agriculture & 1 \\
\hline Electricity & 1 \\
\hline
\end{tabular}

\subsection{Research Findings}

The responses to questions were captured by the research team and cleaned prior to it being analysed. The presentation of findings and analysis was then collated and is presented below. In response to the question which asked respondents to identify what the Municipality could do to address their challenges; the majority of respondents made the following suggestions: 
- the need for business continuity by the City (particularly the rates, and building plan approval functions);

- the need for one source of reliable information;

- the sentiment that smaller businesses such as informal and non-tax compliant businesses have been overlooked by most interventions; and

- the need for a facilitator to assist with accessing national and private sector funds and expedite their assistance where possible.

In response to the question that asked 'What best describes how the Corona Virus epidemic (pre and during shutdown) has affected your revenue?' 93 respondents reported that revenue had decreased, 6 respondents reported that revenue had remained unchanged while 0 respondents reported that revenue had increased. Notably, even medical services firms reported a drop-in revenue while firms which did not see a change in revenue were mainly comprised of research firms who could largely work from home and had long standing contracts.

In response to the question 'How has the Corona Virus National Shutdown affected your business operations?' 69 respondents reported a complete shutdown while 11 reported a significant impact as employees needed to work on site. 6 respondents reported a moderate impact as some employees needed to work on-site. A further 6 respondents reported minimum impact as most employees can work from home while 4 respondents reported other.

The rand value of losses was proportional to the size of the firm, with the average large firm (more than 200 employees) having lost R13,2 million rand in revenue, and the average micro sized firm (including informal sector businesses) having lost an average of R113,000 in revenue over the past month. Medium sized firms reported an average loss of R4,1 million; small firms R700 000 and very small firms R400 000.

\subsubsection{Interventions Raised by Respondents}

The following top interventions were provided by businesses in response to the question 'Please briefly describe realistic interventions which may assist your business to recover from the COVID 19 epidemic?' Interventions raised by 
businesses were wide ranging, but those listed below were the most commonly raised, and collectively add up to $75 \%$ of responses.

\section{Facilitation Role Missing}

One in four respondents $(25 \%)$ stated that they required assistance with accessing national government, and private sector funds. Some indicated that they had already applied and needed their applications expedited, or that they had tried to apply but did not qualify. Reasons included being informal, or nonVAT compliant, not holding existing debt with the institution offering debt relief, being 'non-black', or not being South African. Amongst those that cited not qualifying as an issue, the most frequently mentioned fund was the UIF TERS (Temporary Employment Relief Fund). Some respondents said that their employees were informal or employed on a 'needs basis' (temporary or seasonal employment). One business noted that tax compliance penalises small businesses, as '...both UIF call centres and SARS offices are closed so it will take a long time to sort out compliance', meaning that even if they wanted to comply, they may not be able to do so on time.

Others referred to national government initiatives assisting businesses to produce goods in demand during the pandemic but said that they needed assistance accessing markets to buy the goods. One respondent lamented '...I could supply masks and uniforms to hospitals and other people but I'm only getting hoax emails and it's scary'. Another respondent requested that big businesses who supply such goods should be required to liaise with small business.

\section{Cash Injection Needed}

Over a fifth (22\%) of respondents said that they urgently required a cash injection for increased debts for overhead costs, and for debtor accounts. Some businesses indicated being aware of national government and private sector initiatives which would provide the cash injection, but also indicated that they did not qualify; due to being non-VAT compliant firms, non-South African business owners, or non-bank clients. Nonetheless, urgent cash injection was the second most commonly requested intervention.

\section{eThekwini Municipality Business Continuity}

The third most popular issue raised (14\%) was the need for business continuity; mainly by the Municipality. Businesses noted that as far as possible, those 
departments which most directly facilitate economic activity should work remotely or digitally; even if done on a skeleton staff. The business unit most frequently mentioned is the Rates Department (by estate agents), which would 'allow for a flow of business transactions' despite the lockdown. Estate agents also requested that functions of the Deeds Office in Pietermaritzburg continue to operate, although this is not in the direct control of the Municipality. Respondents in the construction industry raised the need for the Municipality to expedite plan approvals on housing, and infrastructure projects, during the lockdown if possible.

Some businesses felt that after the lockdown, the Municipality requires a new approach to procurement, where processes are made faster, more digitised, and public, without officials 'extorting bribes', and with a wider range of service providers being used. Some construction businesses highlighted a need to fast track the execution of housing infrastructure projects. One respondent highlighted the need for the City to be intentional about procuring locally manufactured products; as opposed to contracting from local companies who import the bulk of their products.

\section{Rates and Rent Relief}

Some businesses (8\%) indicated that a rent and rates holiday from the Municipality would be necessary for their businesses to survive. One respondent noted that the rates holiday should be translated into a discount in rent required by landlords. One business also requested a plan to get landlords to accept part rental at least for March and April until they 'get back onto their feet'.

\section{Consolidated Information Needed}

Some respondents $(7 \%)$ indicated that they needed more information on initiatives available, some noting that they are aware of business opportunities made available by the pandemic, but they do not know where to find the information. Some businesses listed a need for tax breaks, help with salary payments, soft loans, and other aspects of business; all of which is already available. These respondents most frequently cited the need for assistance with paying salaries; with no reference made to the UIF TERS fund. This indicates that they were not aware of the fund at the time of responding and highlights the need for a coordinated effort to disseminate consolidated information.

There also appears to be a concern around accessing information timeously, with one respondent pointing out that '... the Sukuma relief fund 
was great however when we tried to register, they said they had stopped taking applications'.

A small number of respondents (3\%) indicated that there was nothing more that could be done as their businesses had already closed. Other issues less frequently raised include a need for assistance with transportation of essential workers, assistance with digitisation of businesses to ensure resilience during shocks and termination of 'harassment' by metro police.

\section{Food Parcels Needed}

Finally, the cross between social and economic needs is exacerbated by the pandemic. There is a need for food parcels, mainly for the informal sector which largely does not have enough safety mechanisms such as savings and (legal) credit. One (street trader) respondent lamented needing both assistance to start afresh and buy stock, as well as food parcels. The same respondent noted '...because of this lockdown I used all the money for stock...the little that I was trying to save is also used because I don't have a job. I only depend on selling clothes on the street'. Solutions should therefore not only be focussed on business, but on the socio-economic health of (especially informal) business owners. There are approximately 43000 permit holding street traders and informal businesses in Durban. The number of informal businesses is greater, as not all businesses are permit holding. This indicates the scale of the socioeconomic need.

\section{5 eThekwini Municipality's Economic Response to Covid-19}

The City's economic response was based on a combination of the results of the survey, an analysis of economic performance of the national and local economies, the national relief measures as well as initial learnings from other cities. The City's plan seeks to support enterprises, safeguard jobs while caring for livelihoods. The Economic Recovery Plan (ERP) is based on the following eight key pillars (eThekwini Municipality 2020b).

\subsection{Monitoring and Responding to the Health of the Municipality and the Economy}

Collection rates for municipal revenue fell from 94\% in February 2020 to 56\% in April 2020. This amounted to an under collection of about R1,5 billion in 
April 2020 while projections show that May and June 2020 will be equally adverse (eThekwini Municipality 2020). The ERP estimates that it will take at least 18 months before economic activity returns to pre-lockdown levels. Based on economic modelling, it is estimated that at level 4 of the lockdown the City is estimated to be operating at $34,2 \%$ of its 2018 capacity. It is also estimated that $32,2 \%$ of businesses are operational, although with a reduced workforce, and/ or reduced working hours (The Durban EDGE 2020b). The plan assumes that the risk adjusted strategy will remain in effect until May 2021, possibly at level 1 with some social distancing measures still in place. It is evident that the Municipality's finances will come under severe and sustained pressure over the next 12 to 18 months. It is important that the Municipality remains financially sustainable. Due to the uncertain nature of the current period, the ERP states that the Municipality will not be able to offer blanket approaches to writing off debt. However, at the same time it acknowledges that businesses (as customers) are collapsing resulting in job losses and a resultant decline in its customer base. The ERP hence indicates that the Municipality needs to monitor and predict economic activity while maintaining a fine and delicate balance between its own ongoing financial sustainability and survival of its customer base, while recognising that both are inter-related.

\subsection{Facilitating the City's Share of National Support and Industrial Opportunities}

Feedback from surveys have shown that the relief measures outlined by National Treasury (2020b), in terms of phase one have not been easy to access and very slow in implementation. As part of the early interventions that the Municipality put in place, it identified the informal sector as being not adequately covered by the support measures. In addition, businesses have reported an inability to access support due to inter alia, being non-VAT/tax compliant, unregistered, or non-South African owned. Phase two of the national support is focussed on stabilising the economy and included an extraordinary health budget, support to municipalities in delivering basic services and a debt guarantee facility of R200bn, implemented through the banks (National Treasury 2020b). The ERP also acknowledges that past national government support programmes have recorded an underrepresentation of beneficiaries from KwaZulu-Natal and eThekwini. The ERP 
hence pinpoints that the Municipality will actively assist businesses access the national support programmes through a hotline, online support, and the opening of customer care centres during level 5 of the lockdown. The ERP sets a target of attracting R30 billion of support to businesses in Durban.

\subsection{Re-starting the Tourism Industry}

The ERP indicates that a large proportion of the local labour force is unskilled or low-skilled, while about $80 \%$ of employment created over the last 5 years has been created in skilled or semi-skilled job categories. The Plan identifies eThekwini's tourism sector as playing an important role in creating jobs in the lower skilled labour categories and includes temporary employment. However, according to the Moody's (2020b) Covid-19 Industry Heat Map, the tourism and events industry is in the red category i.e. one with high risk of unsustainability during the pandemic. The travel and tourism industry have arguably been the worst hit by the travel bans and lockdown regulations. The airline industry was brought to a standstill and hotels and accommodation establishments have been vacant since the start of the lockdown, except for rare exceptions where foreign visitors have been housed until they could be repatriated. eThekwini Municipality (2020b) estimates that the local tourism industry lost R600 million in direct spending over the Easter vacation period and stands to lose more than R4 billion by the end of the winter season with 8200 jobs being lost. The ERP identifies tourism as being particularly important for Durban which is the country's number one domestic tourist destination. While the local tourism industry begins to open, there is likely to remain restrictions on international travel, with skepticism related to international travel persisting well into 2022. The ERP provides relief to Bed and Breakfast and guesthouses through a re-designation to residential property rates, while providing rental relief for municipal owned properties that are leased out. The ERP also spells out a re-introduction campaign that starts with soft destination marketing during the lockdown, which is to be followed by a more aggressive domestic market campaign as the restrictions ease, as well as COVID-19 tourism packages.

\subsection{Supporting the Rural, Township and Informal Economy} The ERP has pointed out that the informal sector as well as small businesses 
in the townships and rural areas are the most vulnerable and least likely to receive support from the existing COVID-19 relief programmes. These businesses consist mostly of traders in the retail sector such as street traders, spaza shops, personal services, and restaurants. It also includes home businesses, micro-manufacturing, and the production of construction material, although these are far fewer in number. Large parts of the informal sector operate on a survival basis with little scope for growth. The existing programmes and basic facilities provided by the Municipality allow for the survival of informal businesses, while supporting those enterprises that show potential for growth. Due to apartheid policies, businesses within the informal sector, within townships and rural areas were disadvantaged and had little scope for growth. The ERP therefore recognises that the survival and growth of enterprises in townships and the informal economy are fundamental to addressing poverty and reducing inequality, while creating sustainable jobs and a functional cash economy. With this in mind, the ERP provides a 6-month rental holiday for informal traders while putting a freeze on rental increases in the next year.

\subsection{Creating an Extraordinary Environment for Construction and Infrastructure Investment}

The introduction of the risk-adjusted strategy of government at level 5 resulted in the complete shutdown of construction activity and development in general. eThekwini Municipality (2020b) identified that this caused widespread job losses in the construction industry and a halting of many investments. The Durban EDGE (2020) estimated that approximately R10 billion worth of foreign direct investment (FDI) that was to be invested in Durban was put on hold due to the drop-in demand as a result of COVID-19 and the sovereign rating downgrade. With the resumption of construction activity at level 3 and 4 of the lockdown, and in anticipation of a further opening up of the economy in the coming months, the ERP states that construction activity can absorb the many unemployed and large number of semi-skilled and unskilled labour. The ERP hence seeks to create an extraordinary environment that boosts construction activity to create a stimulus that pushes the economy back onto a growth curve. The ERP does this by providing a one-year waiver of all plan submission fees and moving rapidly to online systems for plan submission. In 
addition, it identifies private and public sector projects worth about R10 billion for fast tracking into construction.

\subsection{Operationalizing the Socio-Economic Relief Fund}

The survey indicated that while national government has announced phases one and two of its economic recovery package, the reality on the ground is that it has not reached many businesses both in the informal and formal economies. In a bid to provide support to failing businesses, stem job losses and fund projects aimed at assisting businesses to access opportunities, the Economic Development and Planning Cluster of the Municipality identified R40 million from within its budget for re-prioritisation into a Socio-economic Relief Fund established by the Municipality. The governance structure of the fund includes oversight from respected members of the local business community along with senior officials from the Municipality. The fund is not intended to duplicate national support measures, but in addition to it. The ERP indicates that funds committed by the Municipality into this fund will be used to attract further funding from the private sector through a fund-raising campaign led by the Mayor.

\subsection{Ensuring Radical Economic Transformation in City \\ Procurement and Expediting Payments to Small Businesses}

The ERP indicates that the fundamental structure of the South African economy was shaped by apartheid which limited and excluded ownership in the economy by Black African people. The post-apartheid era has made significant gains resulting in the growth of a Black middle class. However, deep-seated divisions remain, which is evident in the income profile at the country and city level. The vast majority of poor in the eThekwini area are largely Black Africans. To address the stark inequalities, deliberate and sustained intervention is required at a large scale. Government in general and the Municipality in particular has at its disposal the procurement it undertakes which is sizable and diverse enough to effect change. The ERP directs increased COVID-19 procurement towards Black owned businesses. In addition, it introduces a requirement that all SMMEs are paid within seven days without any penalty fees. 


\subsection{Building Social Coalitions and a Buy-Local Invest-Local Campaign}

The ERP indicates that partnerships and social coalitions are important in a society that wants to address deep-seated issues such as inequality, poverty, and unemployment. Power relations are such that no single actor within a city can effect change in a comprehensive way. While society has given government the mandate to lead, in order to bring about systemic change, there are many actors and stakeholders that need to work together towards a common objective. Shape Durban is identified in the plan as the most broadly participative process undertaken by the City, not only due to the wide variety of participants, but because of the high levels of participation found in its 'cocreation' methodology. During the COVID-19 pandemic, the Municipality has spoken with a common voice with its partners in the Province, Durban Chamber of Commerce, and Industry, and KZN Growth Coalition. This broad partnership, which also finds expression in the oversight structure of the Socioeconomic Recovery Fund will form one of the pillars upon which economic recovery will be based. The plan identified the establishment of the Durban Economic Council as being a critical cross-sectoral inclusive partnership, that will inevitably provide economic direction to the City, presently and in the future.

\section{Conclusion}

The rapid spread of COVID-19 has been concentrated in the cities around the globe. These cities have borne the brunt of the devastation caused by COVID19 and the economic fallout due to the social distancing, lockdowns, and measures to curb the spread of this novel virus. In this phase of rapid change, cities have been responding to the economic crisis in various ways. This has resulted in learnings from cities across the globe, which city professionals have shared through learning networks such as the World Bank's Competitive Cities Programme. Among these learnings have been the case of Durban. EThekwini Municipality, being the local government responsible for this city, has moved relatively quickly in not only putting in place health and social plans in collaboration with National and Provincial Government, but also developed and articulated its economic response to the economic crisis while the country was still at level 5 of the lockdown. The broad coalitions with business that 
were already before COVID-19, played an important role in ensuring that there was a common response that was agreed to by these stakeholders. The plan which has an 18-month timeframe, complements, and supports the measures introduced by National Government aimed at providing relief and economic recovery.

While eThekwini has been dealing with a deep and prolonged economic recession, social, health, financial and unemployment crises and residents that are under severe strain, this article demonstrates how a city that is under severe pressure is showing determination to stage an economic recovery. The Durban case study is hence worth noting and adds to this rapidly developing field and knowledge base on local economic development during the COVID-19 calamity.

\section{References}

Baldwin, R. \& B. Weder di Mauro 2020. Mitigating the COVID Economic Crisis: Act Fast and Do Whatever It Takes. Centre for Economic Policy Research. CEPR Press.

Cairns, P. 2020. 2020. Global Markets Lost Nearly \$8 Trillion in Value in March, and Volatility Hit Record Highs. Available at: Moneywebhttps://www.moneyweb.co.za/investing/global-markets-lostnearly-8-billion-in-value-in-march/

(Accessed on 08 June 2020.)

eThekwini Municipality 2020a. Financial Impact of COVID Lockdown. Treasury Cluster.

eThekwini Municipality 2020b. eThekwini's Economic Recovery Plan. Unpublished document. (Accessed on 05 May 2020.)

Gentilini, U., M. Almenfi, I. Orton \& P. Dale 2020. Social Protection and Jobs Responses to COVID-19: A Real-Time Review of Country Measures. Washington, D.C.: World Bank. Available at:

https://openknowledge.worldbank.org/handle/10986/33635

(Accessed on 20 March 2020.)

Gopinath, G. 2020. The Great Lockdown: Worst Economic Downturn Since the

Great Depression. International Monetary Fund Available at:

https://blogs.imf.org/2020/04/14/the-great-lockdown-worst-economicdownturn-since-the-great-depression/

(Accessed on 08 June 2020). 
Madiba, T. 2020. COVID-19 Highlights Massive Structural Inequality - Bonang Mohale. Engineering News 21 May 2020. Available at:

https://www.engineeringnews.co.za/article/covid-19-highlights-massivestructural-inequality-bonang-mohale-2020-05-21

Moody's Investor Services 2020a. Rating Action: Moody's Downgrades South Africa's Ratings to Bal, Maintains Negative Outlook. 27 March 2020. Available at: https://www.moodys.com/research/Moodys-downgradesSouth-Africas-ratings-to-Ba1-maintains-negative-outlook--PR 420630 (Accessed on 08 June 2020.)

Moody's Investor Services 2020b. Live Markets - Moody's Coronavirus Sector Heatmap. Available at:

https://www.moodysanalytics.com/articles/2020/coronavirus-assessingthe-impact-on-corporate-credit-risk (Accessed on 08 June 2020.)

Nordling, L. 20 April 2020. South Africa Flattens its Coronavirus Curve - and Considers How to Ease Restrictions. Science Magazine Available at: https://www.sciencemag.org/news/2020/04/south-africa-flattens-itscoronavirus-curve-and-considers-how-ease-restrictions (Accessed 08 June 2020).

Odendahl, C. \& J. Springford 2020. The Two Economic Stages of Coronavirus. Centre for European Reform. CER Bulletin Issue 131. Available at: https://www.cer.eu/publications/archive/bulletin-article/2020/twoeconomic-stages-coronavirus

(Accessed in April/May 2020.)

Organisation of Economic Cooperation and Development (OECD) 2020.

Coronavirus (COVID-19): SME Policy Responses. OECD Centre for Entrepreneurship, SMEs, Regions and Cities (CFE). Available at: https://www.oecd.org/coronavirus/policy-responses/coronavirus-covid-

19-sme-policy-responses-04440101/

Quantec 2020. Statistics. Accessed from Quantec Online Subscription Services, updated March 2020.

Republic of South Africa 2020a. Government Gazette No. 43096 of 15 March 2020.

Republic of South Africa 2020b. Government Notice 318 of 18 March 2020. Pretoria: Department of Co-operative Governance and Traditional Affairs.

Republic of South Africa 2020c. Economic Measures for COVID19. Pretoria: National Treasury 28 April 2020. 
Ajiv Maharaj \& Purshottama Reddy

Republic of South Africa 2020d. Government Gazette No. 43258 of 29 April 2020.

Republic of South Africa 2020e. Government Gazette No. 43291 of 07 May 2020.

Republic of South Africa 2020f. Briefing by National Treasury on Financial

Implications of COVID-19 on Both the Economy and Budget Joint

Standing Committee and Select Committee on Finance and

Appropriations. 30 April 2020. Pretoria. National Treasury.

Republic of South Africa 2020g. COVID-19 Risk Adjusted Strategy. Availa-

ble at: https://sacoronavirus.co.za/covid-19-risk-adjusted-

strategy/Department of Health

(Accessed on 08 June 2020).

Republic of South Africa 2020h. Schedule of Services to be Phased in as per the COVID-19 Risk Adjusted Strategy. Schedule of Services Framework for Sectors. Department of Health.

Prichep, E. 03 April 2020. Why a Coronavirus Vaccine Takes over a Year to

Produce - and Why that is Incredibly Fast. Project Lead Precision

Medicine, World Economic Forum. Available at:

https://www.weforum.org/agenda/2020/04/why-a-coronavirus-vaccinetakes-over-a-year-to-produce-and-why-that-is-incredibly-fast/

Statistics South Africa (STATS SA) 2016. Community Survey 2016. KwaZulu-Natal Results Provincial Kwazulu-Natal Profile Report 03-0110.

The Durban EDGE 2020a. State of the Local Economy: Impact of COVID-19.

Unpublished report. Durban: eThekwini Municipality.

The Durban EDGE 2020b. Results of the Economic Model of Lockdown Levels. Unpublished report. Durban: eThekwini Municipality.

World Bank 2015. Competitive Cities for Jobs and Growth: What, Who and How? Washington D.C.: World Bank.

World Health Organisation (WHO) 2020. COVID -19. Strategy Update. Geneva. April.

Worldometers 2020. COVID-19 Coronavirus Pandemic. Available at: https://www.worldometers.info/coronavirus/

(Accessed on 18 September 2020.)

World Trade Organisation 2020. Goods Trade Barometer May 2020. Available at: https://www.wto.org/english/news_e/news20_e/wtoi_19may20_e.pdf (Accessed on 08 June 2020.) 
Local Government's Economic Response to COVID-19

Ajiv Maharaj eThekwini Municipality Ajiv.Maharaj@durban.gov.za

Purshottama Reddy Senior Professor University of KwaZulu Natal

Reddyp1@ukzn.ac.za 